\title{
Experimental model for fibroblast culture ${ }^{1}$
}

\author{
Sidney Mamoru Keira ${ }^{2}$ \\ Lydia Masako Ferreira ${ }^{3}$ \\ Alfredo Gragnani ${ }^{4}$ \\ Ivone da Silva Duarte ${ }^{5}$ \\ Isabel Anunciação Neves dos Santos ${ }^{6}$
}

Keira SM, Ferreira LM, Gragnani A, Duarte IS, Santos IAN. Experimental model for fibroblast culture. Acta Cir Bras [serial online] 2004 Vol 19 Special Edition. Available on URL: http://www.scielo.br/acb.

ABSTRACT - The use of cell culture methods in Plastic Surgery opened a new horizon in the research of cellular mechanisms of proliferation and biosynthesis functions. Several types of cells have been investigated in the cutaneous compartment. Keratinocytes and fibroblasts have been studied aiming the possibility of developing biomaterial for skin substitution. The present study describes the standardization for the development of fibroblast primary culture, its utilization in experiments and its storage.

KEY WORDS - Cell culture. Fibroblasts.

\section{Introduction}

Skin, with a $2 \mathrm{~m}^{2}$ surface, has an important role in the defense of human body against microorganisms from the environment and also in the maintenance of hydric homeostasis ${ }^{1}$.

When skin integrity is broken by wound, the organism begins immediately the healing process using a sequence of biochemical and biophysical events in order to reestablish the skin integrity in the wound site ${ }^{2}$.

Cell culture has been used as an important tool to investigate the healing process. This method permits the study of the biological behavior of skin cells, considering either the cellular proliferation kinetics or the biosynthesis of several components of extra-cellular matrix.

\section{Proposition}

The present study intends to show an experimental model of fibroblast culture with the standardization of the initial process of the cutaneous material and the maintenance of the cell culture.

\section{Method description}

\footnotetext{
${ }^{1}$ Study developed in the Laboratory of Cell Culture, Plastic Surgery Division, Federal University of Sao Paulo - Sao Paulo Medical School.

${ }^{2}$ MD, PhD, Plastic Surgery Division, Federal University of Sao Paulo - Sao Paulo Medical School.

${ }^{3} \mathrm{MD}$, PhD, Titular and Head of the Plastic Surgery Division, Federal University of Sao Paulo - Sao Paulo Medical School.

${ }^{4}$ MD, PhD, Plastic Surgery Division, Federal University of Sao Paulo - Sao Paulo Medical School. 5 MD, PhD, Plastic Surgery Division, Federal University of Sao Paulo - Sao Paulo Medical School ${ }^{6}$ Biomedic, Molecular Biology Division, Federal University of Sao Paulo - Sao Paulo Medical School.
} 


\section{Initial processing of the skin specimens}

Skin material for primary culture of fibroblasts is obtained from surgical specimens that are disposed. These specimens are used once the patients have read and signed a Consent Term.

These specimens of skin are initially processed within the surgical ward, when epidermal and dermal portions of the skin is dissected with scalpels and scissors, disposing the subjacent subcutaneous tissue. The obtained samples are maintained in $50 \mathrm{ml}$ conic tubes with $40 \mathrm{ml}$ of Dulbecco's modified Eagle's medium (DMEM) (Gibco, Califórnia, USA), stored at $4^{\circ} \mathrm{C}$ and processed within four hours in laminar flow.

Initially, the samples are put in $50 \mathrm{ml}$ conic tubes and exhaustively rinsed (eight times) with $40 \mathrm{ml}$ of phosphate buffered saline (PBS) (Sigma Chemical Co., Saint Louis, USA) under vigorous agitation. The conic tube and the PBS are changed at each repetition.

\section{Primary culture of fibroblasts}

Fibroblast harvesting is done by explant, isolating the dermis from the epidermis with scalpels and scissors. Then dermis specimens are fragmented in $5,0 \mathrm{~mm}^{2}$ pieces. These fragments are laid onto the surface of $100 \mathrm{~mm}^{2}$ Petri dishes, in square areas marked by perpendicular lines made with scalpel blades.

The Petri dishes are maintained semi-opened into the laminar flow for 40 minutes in order do adhere the dermis specimens in the culture surface. It is important to avoid desiccating the dermis specimens by instilling physiologic solution over them in order to maintain cellular viability (FIGURE 1).

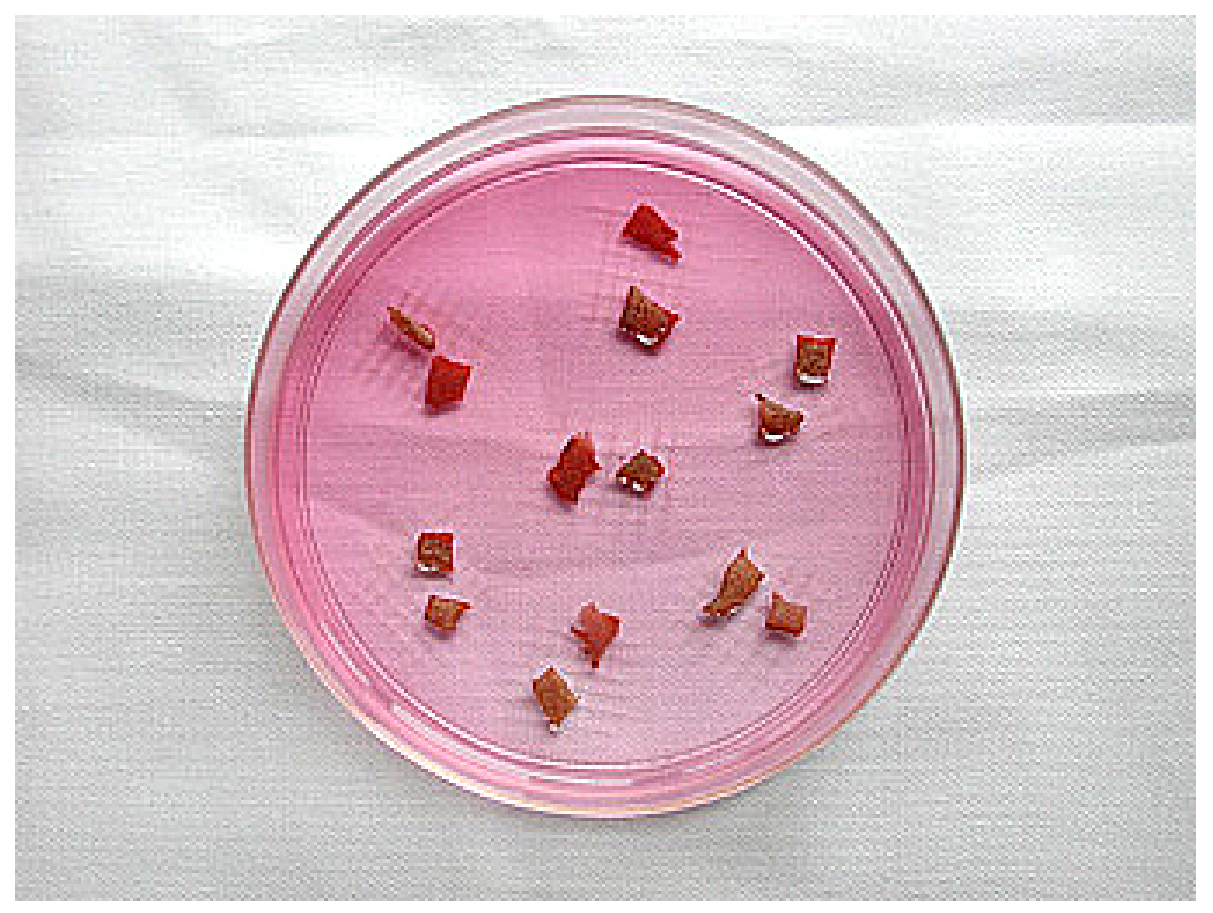

FIGURE 1 - Petri dish with skin fragments in its surface into culture medium after fixation in laminar flow.

Once the fragments are fixed in the Petri dish surface, $10 \mathrm{ml}$ of DMEM with 20\% fetal bovine serum ${ }^{3}$ (Sigma Chemical Co., Saint Louis, USA), penicillin (100 UI/ml) and streptomycin $(100 \mu \mathrm{g} / \mathrm{ml})$, at $37^{\circ} \mathrm{C}$, was poured in the dish.

Then, the culture dish is maintained in a humidified incubator at $37^{\circ} \mathrm{C}$, under $5 \% \mathrm{CO}_{2}$ in air. 
The culture medium is changed every two days, for this rate enables the maintenance of ideal conditions of $\mathrm{pH}$ between 7,6 and 7,8 without non-physiologic upheavals ${ }^{4,5}$. This $\mathrm{pH}$ stability aimed a balance between cellular proliferation and cellular biosynthesis activity of the fibroblasts ${ }^{6}$.

Fibroblast satisfactory proliferation is observed in approximately seven days ${ }^{7}$.

\section{Subculture of fibroblasts}

Subculture (passage) of fibroblasts was done with $80 \%$ cellular confluence in the Petri dish. (FIGURE2).

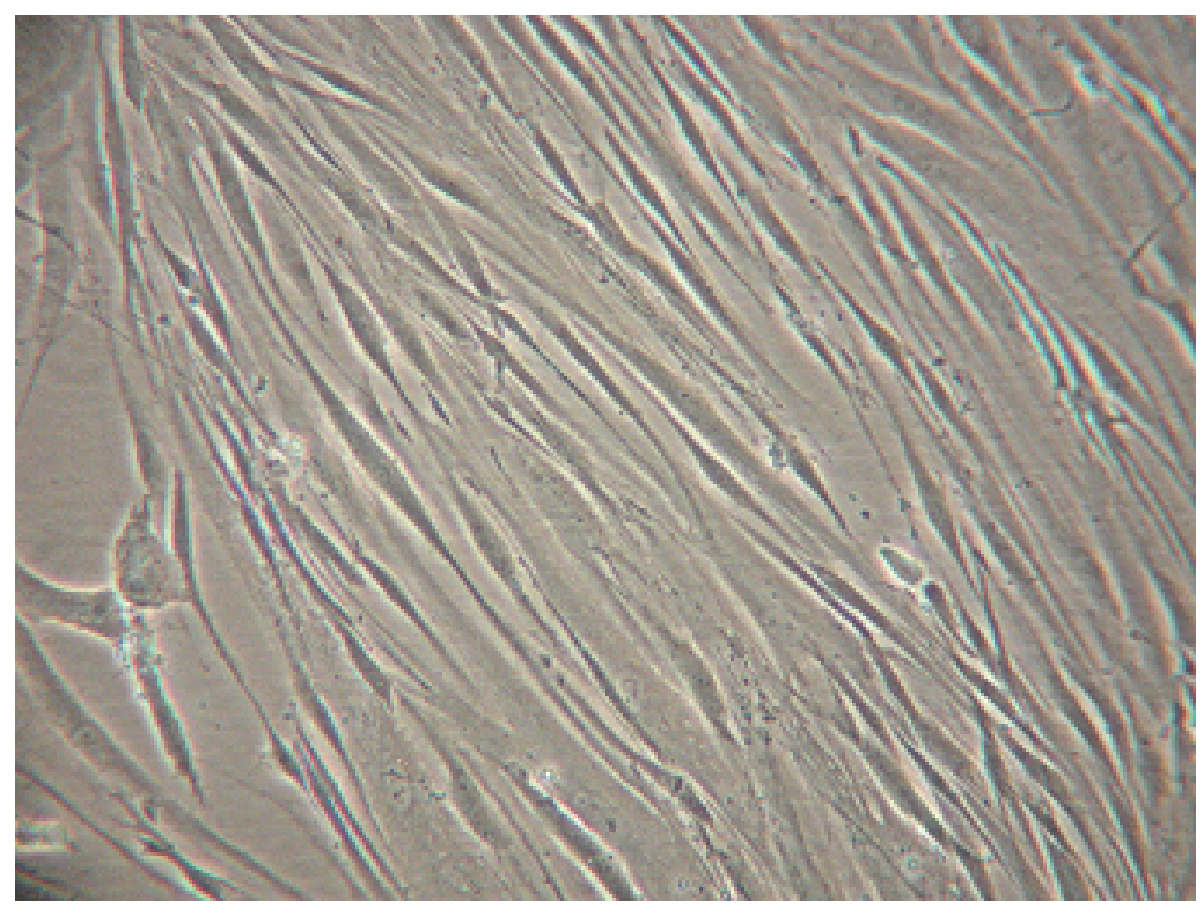

FIGURE 2 - Human fibroblasts in Petri dish with fusiform morphology. (100x magnification)

After aspirating the culture medium, the original skin fragments are removed with pincers. Fibroblasts grown in the Petri dish are rinsed with PBS twice and then, maintained in a humidified incubator with $10 \mathrm{ml}$ of PBS for 20 minutes.

Afterwards, PBS is aspirated and $1 \mathrm{ml}$ of trypsin 0,25\% with EDTA 0,02\% (Sigma Chemical Co., Saint Louis, USA) is instilled in the Petri dish and maintained in humidified incubator for two minutes. Fibroblasts are observed detached from the dish surface with spherical morphology (FIGURE 3), opposite to the fusiform morphology usually observed in fibroblasts (FIGURE 2) or with citoplasmatic prolongation of fibroblasts found scattered in the culture surface (FIGURE 4). 


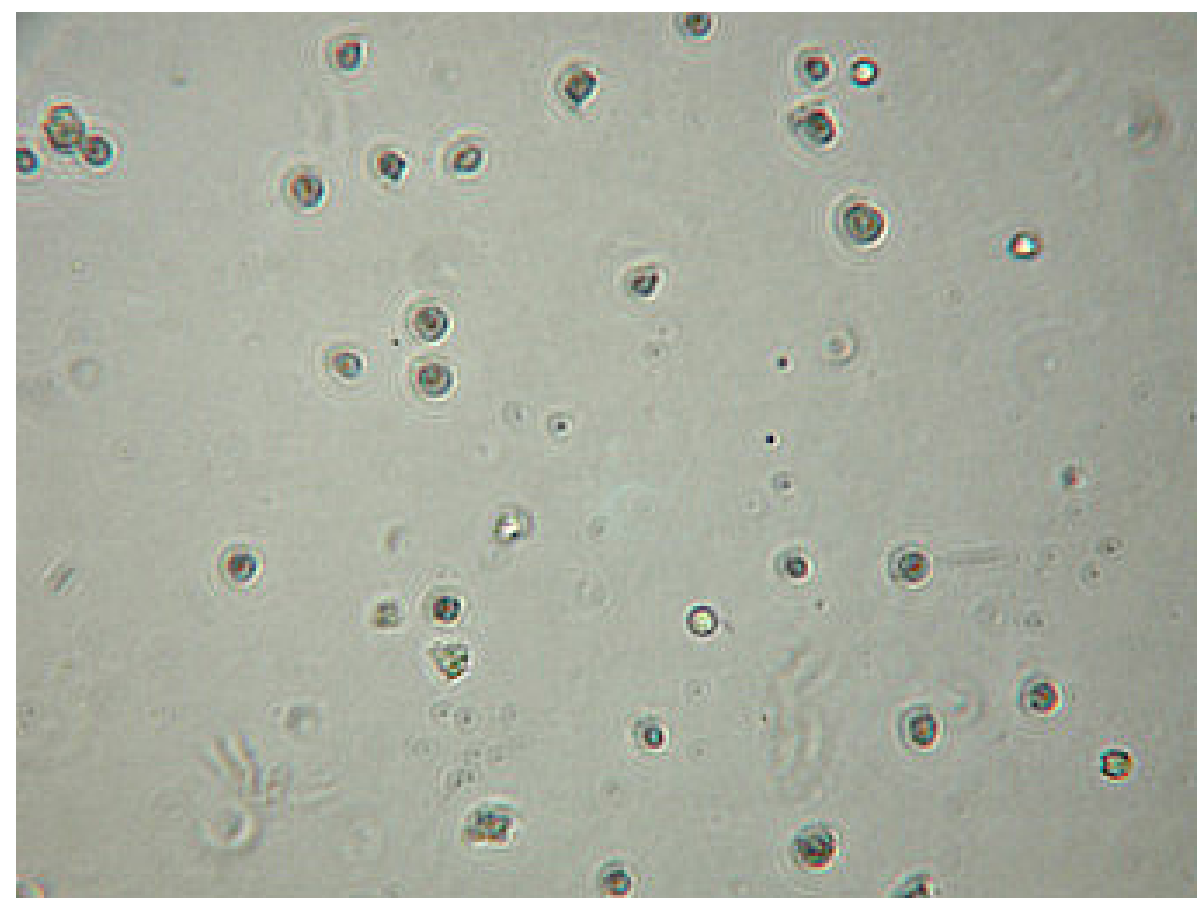

FIGURE 3 - Human fibroblasts in suspension detached from the surface of a Petri dish with spherical morphology. (100x magnification)

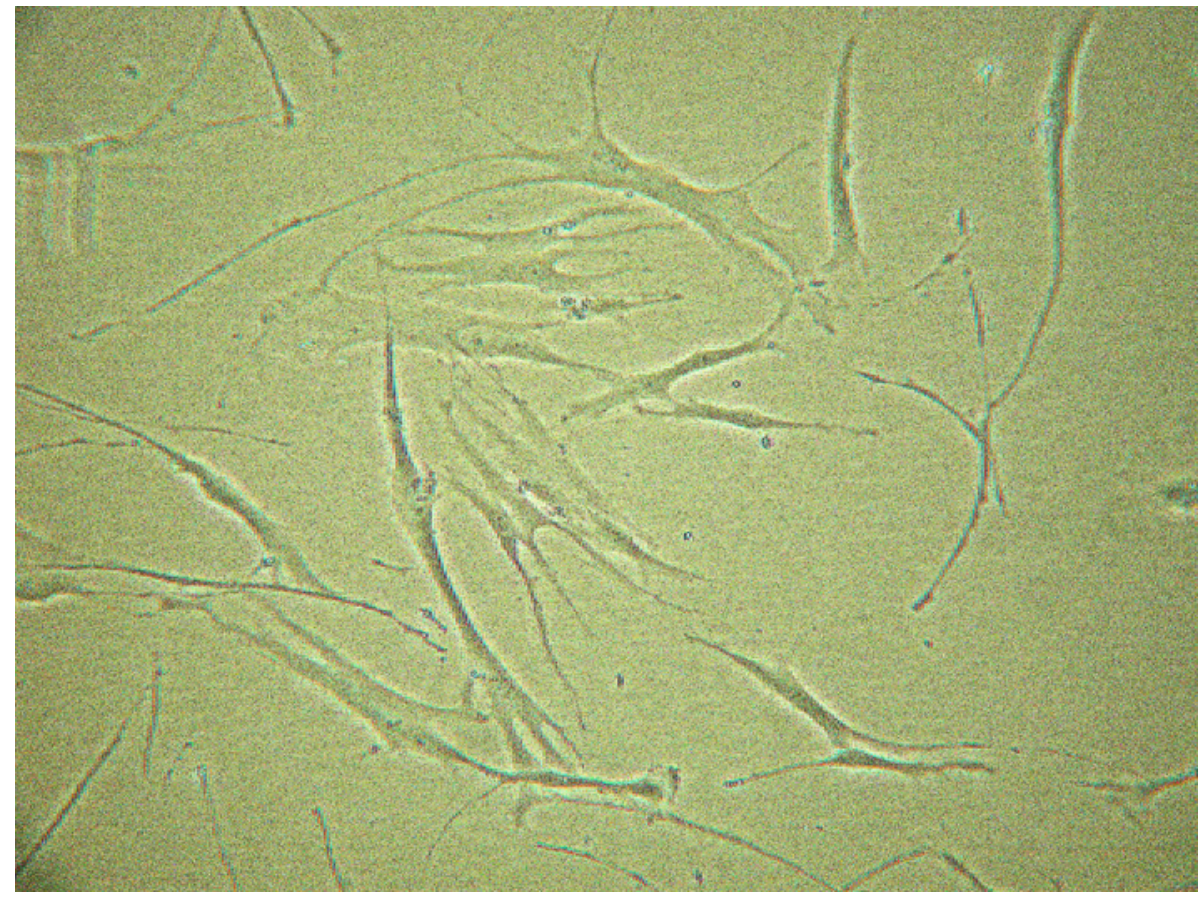

FIGURE 4 - Human fibroblasts in Petri dish with citoplasmatic prolongations (100x magnification).

For neutralization of the enzymatic action of trypsin, 5,0 ml of culture medium supplemented with $20 \%$ fetal bovine serum is instilled in the Petri dish. The cellular suspension is centrifuged $(100 \times \mathrm{g})$ for six minutes. The supernatant (culture medium with neutralized trypsin) is disposed and the cellular pellet is suspended once more in $10 \mathrm{ml}$ of culture medium 
for fibroblasts. This suspension may be stored in nitrogen or used for experiment if cultivated in culture flasks $\left(25,75\right.$ or $\left.175 \mathrm{~cm}^{2}\right)$.

\section{Fibroblast storage in nitrogen}

In the third passage, fibroblasts were frozen for final storage in nitrogen.

After suspending the detached fibroblasts in 5,0 ml of culture medium, cells are counted in a Neubauer chamber. Then this solution is once more centrifuged and suspended again in 5,0 $\mathrm{ml}$ of storage solution (DMEM with $20 \%$ bovine fetal serum and $10 \%$ dimethylsulfoxide) $^{5}$ at $4^{\circ} \mathrm{C}$. These cells are transferred to five cryotubes containing $5,0 \times 10^{6}$ to $10,0 \times 10^{6}$ cells in a volume of $1,0 \mathrm{~mL}$.

These cryotubes are immediately transferred to a freezer at $-20^{\circ} \mathrm{C}$, where they are maintained for 30 minutes. Afterwards, the cryotubes are placed in a freezer at $-80^{\circ} \mathrm{C}$ for 24 hours. Finally, they are stored in liquid nitrogen at $-196^{\circ} \mathrm{C}$, where they can be maintained indefinitely.

\section{Fibroblast experimental culture}

In experimental culture, fibroblasts are used between the fourth and seventh passage in order to avoid the influence of plasmatic factors ${ }^{9}$ and senescent changes in the cellular morphology.

A standard amount of fibroblasts is cultivated $\left(1,0 \times 10^{5}\right.$ cells) in $75 \mathrm{~cm}^{2}$ flasks and maintained at $37^{\circ} \mathrm{C}$, under $5 \% \mathrm{CO}_{2}$ in air, changing the culture medium every 2 days.

The culture medium consists of $10 \mathrm{~g} / \mathrm{L}$ DMEM, 3,7 g/L sodium bicarbonate (Merck, Darmstadt, Germany), 2,4 g/L HEPES buffer (Sigma-Aldrich Chemical Co., Saint Louis, USA) and $10 \%$ bovine fetal serum in distilled water filtered through $0,22 \mu \mathrm{m}$ cellulosic membrane. Additional components may be used depending on the aim of experience.

\section{Perspectives}

The standardization of conducts in processing the skin specimens, establishment of primary culture of fibroblasts and in the proceeding of maintenance showed satisfactory in experiments with fibroblast culture in order to investigate cellular proliferation kinetics and biosynthesis functions ${ }^{7,8}$.

\section{References}

1. Spira M, Stal S - Basal and scamous cell carcinoma of the skin. In: Grabb and Smith's Plastic Surgery. 4 ed. Smith J. W., Aston S. J. (Eds.). Boston: Little, Brown and Company 1991;731:58.

2. Peacock Jr EE, Cohen IK - Wound healing. In: McCarthy JG (Ed). Plastic Surgery. vol 1. Philadelphia: W. B. Saunders Company 1990;161:85.

3. Pinnell SR - Regulation of collagen synthesis. J Invest Dermatol. 1982;79(Suppl. I):73s-6s.

4. Booth BA, Polak KL, Uitto J - Collagen biosynthesis by human skin fibroblasts. I. Optimization of the culture conditions for synthesis of type I and type III procollagens. Biochem Biophys Acta. 1980;607(7):145-60.

5. Ceccarini C, Eagle $\mathrm{H}-\mathrm{pH}$ as a determinant of celular growth and contact inhibition. Washington: Proc Nat Acad Sci. 1971;68:229-33.

6. Dougherty RM - Use of dimethyl sulphoxide for preservation of tissue culture cells by freezing. Nature. 1962; 193:550-1.

7. Nigra TP, Martin GR, Eagle H - The effect of environmental $\mathrm{pH}$ on collagen synthesis by cultured cells. Biochem Biophys Res Commun. 1973;53(1):272-81. 
8. Switzer BR, Summer GK - Collagen synthesis in human skin fibroblasts: effects of ascorbate, $\alpha$ ketoglutarate and ferrous ion on proline hydroxilation. J Nutrition. 1971;102:721-8.

9. Diegelmann RF, Cohen IK, McCoy BJ - Growth kinetics and collagen synthesis of normal skin, normal scar, and keloid fibroblasts in vitro. J Cell Physiol. 1979;98:341-6.

Keira SM, Ferreira LM, Gragnani A, Duarte IS, Santos IAN. Modelo experimental para cultura de fibroblastos. Acta Cir Bras [serial online] 2004 Vol 19 Edição Especial. Disponível em URL: http://www.scielo.br/acb.

RESUMO - A utilização de métodos de cultura de células em Cirurgia Plástica abriu um novo horizonte na pesquisa dos mecanismos celulares de proliferação e biossíntese. Vários tipos de células têm sido investigados no compartimento cutâneo. Os queratinócitos e os fibroblastos têm sido estudados objetivando-se o desenvolvimento de biomateriais para substituição de pele. O presente estudo descreve uma padronização metodológica para o estabelecimento de uma cultura primária de fibroblastos, sua utilização em experimentos e seu armazenamento.

DESCRITORES - Cultura de células. Fibroblastos.

Conflito de interesse: nenhum

Correspondence:

Fonte de financiamento: nenhum

Sidney Mamoru Keira

UNIFESP-EPM, Plastic Surgery Division, Surgery Division

Rua Napoleão de Barros, 715, $4^{\circ}$ andar

04024-900 São Paulo - SP

Tel: (11)557604118 FAX: (11) 55716579

sandra.dcir@epm.br

keirasmps@uol.com.br 